\title{
The Privilege of Voice as a Criterion for Sociolinguistic Inequalities
}

\author{
Anna-Christine Weirich \\ Goethe-University \\ Germany
}

\section{Introduction}

toujours toujours quand on cherche un travail (.) ils nous demandent <<indirect speech, imitates potential employer $>$ est-ce que vous êtes bilingve> non monsieur je suis trilingue $<<$ indirect speech, imitates potential employer $>$ ah oui quelles langues vous parlez anglais espagnol $>$ non russe et roumain $<<$ indirect speech, imitates potential employer $>$ ah désolé non vous devez être bilingue avec anglais> (Natalia ${ }^{1}$, July 2020)

Natalia had invested a lifetime in shaping and enhancing her voice in everyday life, living in rural areas in the Republic of Moldova and Romanian towns where she attended school to study medicine. Immigrating to Canada, she temporarily gave up this voice. Her linguistic repertoire in Québec did not have the same scope as it did in Moldova. In Montréal, she had to learn French to make herself understood in everyday life. Looking for jobs, she was confronted with her medical degree not being recognized and her mastery of French and English was considered insufficient. More than that, her extensive multilingualism is not accepted as "bilingualism" in a sense expected and "majorized" (Weirich, 2014) in Montréal. The majorized linguistic repertoire in Canada is entirely different from that of the Republic of Moldova.

Drawing on a theoretical framework for describing linguistic inequalities with the notions of scope and access (Weirich 2018; Weirich 2021a), this article discusses how far the idea of "voice" understood in the metaphorical use of "being able to speak" and "to be heard" (hooks 1989/2015, p. 5; 1999, p. 338; Hymes, 1983/1996, p. 64; Juffermans \& van der Aa, 2013, p. 112; Wolfram, 2018) is appropriate for defining the aim of language learning processes as strategies to overcome sociolinguistic inequalities and marginalization. This work draws on Hymes' (1983/1996) notion of voice to ask how much voice, in this sense, depends on one's linguistic resources and can be analyzed with (socio)linguistic methods. Voice (in the sense of "making yourself heard") can describe sociolinguistic inequalities related to speakers' potential to make themselves heard and understood. However, I suggest using voice on an abstract level of discussing which groups and individuals have the possibility to get heard while drawing on other (sociolinguistic) notions in empirical analyses that can describe concrete manifestations of linguistic inequalities. In doing so, this paper discusses scenarios of rupture in linguistic biographies as it relates to mobility and illustrates them with the example of Natalia from research in Montréal. ${ }^{2}$ The biographic interview shows that the conditions for having voice depend on sociolinguistic power relations in different societies but that they can be convincingly described with the same theoretical framework. Natalia's narrative also illustrates that having a voice depends not only on sociolinguistic relations, but also on other socioeconomic and political factors.

When using the notion of voice we also have to be aware, that, in current public discourses, refering to voice sometimes serves as justification for liberal ideas of participation and diversity (see Weirich et al., in this number). Having a voice may often be a sign of political and socioeconomic privileges, but it does not guarantee in itself equity and prosperity.

\section{Linguistic relations and linguistic repertoires}

My doctoral research in the Republic of Moldova (2012-2016) resulted in the development of a theory of linguistic relations (sprachliche Verhältnisse), linguistic repertoires, access (Erreichbarkeit), and scope (Reichweite) that provides a framework for interpreting the linguistic dimension of social inequalities (Weirich, 2018; Weirich, 2021a). It aims to better understand how the rupture and transformation of linguistic relations affect multilingual speakers with diverse repertoires. From the individual and ontogenetic perspective, the ethnographic repertoire approach convincingly describes how plurilingual individuals deal with a multilingual environment, while occupying a specific social position:

Voice, as we know, is subject to normative judgment - one has voice when someone else ratifies it as such. In that sense, our subject's repertoire is a complex of traces of power: a collection of resources our subject had to accumulate and learn in order to make sense to others, that is, in order to operate within the norms and expectations that govern social life in the many niches in which he dwelled and through which he passed. The elements of the repertoire are resources he needed to deploy, practices he had to perform, in order to be 'normal' in the polycentric and dynamic world in which he lived. (Blommaert \& Backus, 2011, p. 23) 
Sociolinguistic inequalities are rooted in linguistic relations (see also Weirich, 2018, p. 51; 2021a) that exist between every language, variety and register practiced in a given space, including linguistic ideologies that influence their evaluation. These relations depend on the distribution of linguistic resources, their functions, evaluations, role in regulating access to political and economic participation, and accessibility in learning. Linguistic relations are dynamic, and they can undergo dramatic changes in times of social rupture and redefinition of social power relations. Linguistic relations are part of social relations - they are interdependent upon economic relations, gender and race. Therefore, understanding sociolinguistic equality must also be about defining the place of language and of the individual's capacity to express oneself in a given context, which depends on more than just the individual's and society's linguistic resources and norms.

\subsection{Mobility and Fissures in Sociolinguistic Relations}

Developing voice is a challenge in any society and historical situation. Understanding how linguistic relations work and learning powerful ways of speaking under these conditions can take years of learning and practice, and it needs empowerment. Individuals and groups can also lose their voice when specific linguistic relations change. From a biographic perspective, "fissures" are moments that change the course of everyday life. They can arise because of biographic events (e.g. entering school, starting a job or migrating) as well as politico-historical caesuras.

Mobility is a crucial factor in the way repertoires ${ }^{3}$ are thought to be changing (Blommaert, 2010). Since linguistic repertoires are indexical biographies that directly show the speaker's itineraries (Blommaert \& Backus, 2013), they provide access to certain scales (of formality) and social spaces and are crucial for social mobility. Mobile speakers change their daily environment and confront new linguistic relations (see Weirich 2021a a for a more ample discussion). They have to adapt to a different linguistic environment, in which they strive for voice. Typically, this is thought of as learning one or several new language(s), like French and English in Natalia's case in Montréal. Migrating to (un)officially multilingual societies is particularly challenging. If the majorized linguistic repertoire is multilingual, knowledge of several languages is the condition for participation and voice (cf. Horner \& Weber, 2018, for trilingual Luxemburg). Still, it can also be the confrontation with other varieties and, more importantly, different ideologies and evaluations (see, for example, Boudreau, 2016). Typically, these linguistic relations are initially not contested because they are perceived as legitimate and given: "every social context is normative, and most contexts are normative because the norms are seen as 'normal”' (Blommaert, 2008, p. 428).

Ultimately, a critical notion of having a voice should not only be concerned with an individual's capacity to linguistically play by the rules, as it seems to be the tendency of common discourses about voice (cf. Weirich et al., in this number). It should also reveal the speaker's power and resources to question linguistic ideologies and evaluations.

\subsection{Access, scope, voice}

Access and scope (Weirich, 2018) help to describe the social functions that specific linguistic resources have (scope) and how speakers are positioned to acquire these resources (access). This concept pair captures speakers' relationship to their linguistic resources as currently (un)available (scope) and potentially (un)learnable (access), depending on the social context in which they are practiced. The scope of linguistic resources is constituted by the functions and possibilities of action that certain linguistic resources open up to speakers under specific sociolinguistic circumstances, including the potential for voice. Scope entails such aspects as the practical communicative use, and the possibilities to commodify and participate in a democratically legitimated state. But it also captures aspects like social capital and privileges related to voice and recognition.

\subsection{Voice as a privilege}

A high scope of a linguistic repertoire means having voice in various social situations, drawing on diverse forms of speech, as represented by Bakhtin's oft-cited term 'heteroglossia' (in Russian: raznorečie) (Bakhtin, 1981). Access to linguistic resources depends on a speaker's opportunities to learn specific languages, registers and linguistic forms. Access, from the perspective of usage-based theory, which is the basis of the repertoire approach, depends on use: that is, on opportunities to listen to, speak, read and write the language in question (Zeiter, 2019b). bell hooks (1999) convincingly illustrates that this is true for language learning processes in the narrow sense of acquiring new constructions (form-meaning pairs) as well as for voice: "To make my voice I had to speak, to hear myself talk - and talk I did - darting in and out of grown folk's conversations and dialogues, answering questions that were not directed at me, endlessly 
asking questions, making speeches." (p. 337). For privileged speakers, a relatively high scope of linguistic resources corresponds to a relatively high degree of access to these resources, for example, because of the family language(s), exposure or access to education. Fissures in sociolinguistic relations cause speakers' repertoires to have different scopes. Restructuring processes are triggered (at a different pace) when speakers start to adapt to the new circumstances - and not all speakers are equally successful in doing so.

Lacking voice means being discriminated against (not being listened to, not being taken seriously), because of the way a person speaks - but also because of social positions that serve as pretext to deny voice regardless of how it might sound. "Unlike the black male preacher whose speech was to be heard, who was to be listened to, whose words were to be remembered, the voice of black women - giving orders, making threats, fussing - could be tuned out, could become a kind of background music" (hooks, 1999 , p. 338). This negative definition infers that voice should be understood as a privilege. Those who have privilege usually do not see it (and often deny having it) (Mclntosh 1988; 2012), yet its absence is felt much more vitally than its possession (Amesberger \& Halbmayr, 2008). Among Mclntosh's famous list of 47 white privileges, (only) two are privileges of voice: "10. I can be fairly sure of having my voice heard in a group in which I am the only member of my race. 11. I can be casual about whether or not to listen to another woman's voice in a group in which she is the only member of her race." (Mclntosh, 1988, p. 5) While the former reflects the freedom to have her voice heard, the latter is the privilege to choose to listen to other voices (or not):

I was given cultural permission not to hear voices of people of other races or a tepid cultural tolerance for hearing or acting on such voices. I was also raised not to suffer seriously from anything that darker-skinned people might say about my group, 'protected,' though perhaps I should more accurately say prohibited, through the habits of my economic class and social group, from living in racially mixed groups or being reflective about interactions between people of differing races. (Mclntosh, 1988, p. 9)

Not any aspect of racial privilege or inequity is primarily a question of voice, but most are related to it in one way or the other. This can be illustrated by means of the first privilege mentioned by Mclntosh (1988, p. 4): "1. I can if I wish arrange to be in the company of people of my race most of the time." The hegemony of white spaces (in the US and European societies) is the result of unequal access to spaces and forms of exclusion. Socially significant spaces like Universities in these countries are overwhelmingly white spaces that reproduce white privilege - and as a consequence they are hard to access (and hard to endure) by BIPoC. As a consequence, racial inequity in access to education and in the production of academic knowledge are reproduced. One effect of this is that for example indigenous voices are heard more rarely in these spaces and another one is that indigenous people lack access to practices of speaking and writing in registers characteristic for these institutions. The privilege of voice intersects with other privileges stemming from whiteness (or the relevance of race for recognition of speaker positions). This privilege does not primarily depend on linguistic capacities (Weirich et al., in this number, for a more ample discussion; see also Hymes, 1996, p. 70; hooks 1999, p. 338; Pavlenko, 2005, p. 218; Siegal, 1996). The capability to express oneself in the languages and registers expected in a given context is insufficient for being heard - but a necessary prerequisite. Like Hymes (1983/1996) and Heffner (2013), McIntosh (1988) underlines the role of the hearer for having voice.

\section{Finding voice - again and again}

Natalia is a permanent resident of Québec. She was born in the Moldovan Socialist Soviet Republic (MSSR) in 1980. From 1944 until 1991, Moldova was a Republic of the Soviet Union. In this period, there was no official state language, but Russian and Moldovan, the name of the titular language at the time ${ }^{4}$, were de facto co-official. Russian was the more prestigious language, dominant in the political and economic spheres as well as higher education. As it was indispensable for social mobility, "ethnic" Moldovans like Natalia's family tended to be bilingual in Romanian/Moldovan and Russian. The 1989 Language Laws established a single state language, while simultaneously granting Russian a special status and providing rights for other minority languages. The conflictive role of Russian and its centrality to the linguistic repertoires of all allophones in Moldova are central to the discussion surrounding problems of participation and voice in Moldova (cf. Weirich 2021a).

The three interdependent language laws that introduced monolingualism in Romanian/Moldovan in 1989 also officially changed the alphabet for writing it from Cyrillic to Latin. When the new alphabet was introduced, Natalia was nine years old and in the fourth grade. This was not the only fissure in sociolinguistic relations that she has confronted in her life. The school in her village only provided nine years of education. Thanks to a scholarship provided by the Romanian government, she was able to go to 
high school in Romania, $250 \mathrm{~km}$ away from her hometown. However, this opportunity confronted her with her first migration experience into a foreign country at an early age.

Early on, Natalia was confronted with hegemonic language ideologies of purism and correctness that legitimize some voices and delegitimize others. "Speaking correctly" was an important educational goal which makes legitimate ways of speaking particularly hard to access. In many social contexts in the Republic of Moldova, vernacular language consists of regional forms and translanguaging with forms associated with Romanian and Russian. Simultaneously, most speakers place great value on speaking standard Romanian in institutional contexts, regardless of their linguistic competencies. Notions towards language are not neutral, but related to "the many other ways in which we make sense of the world" (Heller, 2008, p. 518). Culture-specific language ideologies underpin the reproduction and distribution of linguistic resources. While attending school in Romania, Natalia's vernacular was associated with the Republic of Moldova, which tends to be a pretext for glottophobic attitudes among Romanian speakers. The Moldovan vernacular had less scope in Romania, although it was comprehensible to classmates and teachers of Romanian origin:

DA (.) o fost greu (.) ă: dar nu imposibil (.) în ce sens (.) ă: eu proveneam dintro familie de români (.) la mine şi mama e vorbitoare de limba română şi tata vorbitor de limba română (.) eu aveam cuvinte / mai degreabă regionalisme care le utilizăm (.) nu atât cuvinte ruseşti rusisme cât regionalisme (.) şi atunci eu aveam pur şi simplu accentu (.) diferit [...] şi iată când vorbim fără să ne dam seamă / şi am făcut diferenţa introadevăr când ne am dus in romanla (.) eu am făcut diferenţa că DA (.) este limba română şi limba (.) ă: (.) moldovenească doar când am văzut diferenţa între accente şi între cuvintele care le utilizăm (.) ă: (.) deci eu n-am fost // pentru mine n-a fost problema să inţeleg inţelegeam perfect şi ei mă inţelegeau perfect (.) dar totodată cum [...] cum aici mă cunosc îs imigranta că am accent (.) exact aşa şi acolo (.) deodată mă recunosteau că am accent (.) în timp (.) la un an doi deja numai cunoşteau (.) vorbeam (.) vorbeam corect bine în română numai cunoşteam (.) da la inceput introadevăr (.) mă recunoşteau

English (author's translation): "YES, it was difficult but not impossible. In what way? I am from a family of Romanians. My mother speaks Romanian and my father speaks Romanian. I had words, regionalisms that I used. Not so much Russian words, but regionalisms. And at that time, I just had a different accent. And when I spoke without paying attention. In fact, when I went to Romania, I knew that there is a difference in the Romanian and Moldovan languages when I saw the differences in accents and the words we used. I had no problem understanding and they understood me perfectly. Just like here where they recognize that I am an immigrant because of my accent. It was the same thing there. They recognized me immediately because I had an accent. But after a year or two they did not recognize me anymore. I spoke correctly, good Romanian. They did not identify me anymore, even though they did in the beginning."

In the context of school and education having a voice is directly linked to educational success and operates turnouts for future socioeconomic mobility. Natalia experienced a difference in varieties of spoken Romanian in her hometown and in the town where she went to school that she was not aware of before. Although she had no difficulties of intercomprehension and learned to conform to the unmarked variety of Romanian, she was categorized as a "stranger" because of her way of speaking. This points to the role of the listener without whom a voice remains unheard. The readiness to listen and to try to understand is a prerequiste for voice, and it is an attitude that often relies on non-linguistic factors of belonging and social positioning as criteria - or linguistic factors that do not stand in the way of intercomprehension (such as accents).

During her years in high school (liceu), Natalia frequently returned home on weekends and developed a highly differentiated approach to having voice in different contexts which required different socio- and dialectal forms:

eu nici o dată nu mi a plăcut să mă întorc acasă în sat şi cu vecina [...] să vorbesc română curată (.) eu când treceam (.) <laughs> graniţa (.) eu vorbeam (.) cum se vorbeşte la noi în moldova cu un cuvînt rusesc cu un cuvînt românesc cu accentu altfel (.) când mă duceam la mamică la şcoala mamica fiind profesoară (.) eu vorbeau frumos [...] trebuie să-ţi dăi la nivelul cu cine vorbeşti (.) dacă eu am să le vorbesc întro limba curată şi matuşa înţelege / n-are să mă inţeleagă şi atuncia vorbeam cum trebuie să vorbesc cu matuşa şi vorbeam cu profesoară şi ştiam că e profesoară şi inţelege vorbeam cum trebuieşte (.)

English (my translation): "I never liked coming home and speaking with the neighbors in pure Romanian. (laughs) When I crossed the border, I spoke like we speak in Moldova with a word in Russian, a word in Romanian and with a different accent. I spoke properly when I went to see my 
mom at school, because my mom was a Romanian teacher. You have to adapt yourself to the level of the person you are speaking with. When I speak to an aunt in a pure language, she cannot understand me, so I speak to her as I need to and when I was speaking to a professor and I knew it was a professor, I spoke as I had to."

The scope of linguistic resources and linguistic repertoires varies across contexts (Weirich 2021a). In local contexts, vernacular resources can be indispensable for having voice. Speakers who interact on different scales need to acquire resources appropriate to these different contexts to have voice on all scales (Hymes, 1983/1996, p. 66).

Looking back on the language ideologies that she grew up with, Natalia sees a difference between the rather normative overall attitude towards linguistic correctness that reigned in Moldova and Romania and the more "open" attitude in Québec. Language ideologies and normativism can silence or empower voices. Being afraid to speak can prevent speakers from using their voice. Only in use a repertoire has scope and only in use a voice can be listened to at all. However, in spite of the fact that she encounters fewer glottophobic attitudes in daily life in Québec, she feels discrimination on the labor market as an L2 French speaker. She makes the experience of many 'allophones' in Québec, to be ethnically differentiated from the 'Québécois de souche' (Das, 2008, p. 234):

aşa am crescut întro [...] întro societate în care dacă întrebai insemnai că erai prost (.) dacă nu ştiai ceva cu atît mai mult erai prost (.) dacă deschidai gura să zici ceva şi greşeai (unv.) se uită la tine şi aşa te examinau urît că ai greşit (.) să vin aici să văd cât de tAre lumea e deschisă (.) [...] sintem daţi la o parte din punctu de vedere că ne aranjăm la lucru (.) da (.) cautăm nuştiu ce sau nu anume te iau că eşti imigrant (.) că ai stampila aicia pus de imigrant [...] dar in societate în general când te duci la magasin ieşi undeva în parc sau ceva daca ai vorbit şi nu: (.)

English (my translation): "I grew up in a society where asking meant that you are stupid. If you didn't know something, it meant that you are even more stupid. If you opened your mouth and said something wrong, they looked at you unpleasantly, because you said something wrong. And then I came here and saw how open people can be. We are looked over when it's about finding work. We are looking for something else or they do not take you because you are immigrant. But not in society in general, when you go to a shop or to the park."

Economic reasons informed the decision by Natalia's family to immigrate to Québec, where they could apply for permanent residency as a family. If they had stayed in Moldova, Natalia explains, one of them would have needed to go abroad in order to earn money for the family and they could not have stayed together, which was their highest priority. The socio-economic situation in the Republic of Moldova causes labor migration on a vast scale. Since 2009, more than 800 Moldovans have immigrated to Québec annually, making Moldova the most represented East European country of origin (9.7\% in 2016). However, in relation to the high emigration rate of Moldovans, only a small proportion goes to Canada (Weirich, $2021 \mathrm{~b}$ ). Linguistic knowledge plays a role in migration decisions (and in the case of Canada and Québec also in the authorities' decisions to provide visa or not) but seldom seems to be a decisive criterion. Natalia and her family decided to immigrate to Québec with only a basic account of French and without knowledge of English, hoping to (re)aquire voice in practice.

Natalia had studied medicine and worked as a family doctor. She had developed resources in Romanian and Russian. She had invested thirty years in shaping and enhancing her voice in everyday life in Moldova and Romania and the professional context of medicine. Permanently emigrating to Québec at the age of 30 , she gave up her linguistic privileges and had to restructure her linguistic repertoire, overcoming various barriers to learning and communicating. Her linguistic repertoire did not have the same scope in Québec as it did in Moldova. Once she arrived in Montréal, she started learning French to make herself understood in everyday life and to find work. Her explanations show that she has adopted French-English bilingualism as 'majorized repertoire' (Weirich, 2014) and considers it the ultimate target of language learning. Representations of majorized repertoires posit (named) languages and varieties as being more or less accessible, in a perspective of potential appropriation. She says that learning new languages comes difficult to her:

je ne parle pas encore cent pourcent français (.) bien français je me débrouille (.) je suis toujours à l'aise MAIS (.) ă: (.) j'ai des choses à apprendre quand même (.) <laughs> [...] pour les autres langues ă: (.) non j'ai j'ai parle pas anglais encore (.) ă: (.) j'ai suivi une cours d'anglais (.) ă: (.) je me suis enlevé la barrière parce que j'ai eu vraiment une barrière (.) je ne suis pas à l'aise avec les langues (.) vraiment je suis pas à l'aise ça me tombe tellement difficile (.) je dois étudier fort (.) pour pouvoir parler une langue étrangère (.) pour ça j'ai eu comme une barr (.) barrière parce que dans notre langue maternelle dans la langue roumaine (.) tous les lettres qui on écrit le son s'en vienne 
(.) le même son (.) mais (.) en anglais c'était beaucoup de lettres (.) une seule son (.) c'était pour ça que j'ai eu cette barrière (.) difficile de le (.) de la dépasser (.)

Natalia describes several sorts of barrier to having a voice. One such barrier is writing: learning how to write French was difficult for her, but she had various strategies at hand to overcome these obstacles. She knew means to help herself, like using dictionaries, and she dared to write, even at the risk of committing errors to make herself understood and to get the necessary practice. It is even more difficult to have a voice in writing than in speaking because of the hegemonic monolingualism applied to writing (Sebba, 2013 ; Weirich 2021c). Purism and the expectation of correctness guide the perception of written language in most contexts, and they strongly influence writers' judgements of their own texts. Natalia has developed a self-empowering attitude by means of a certain tolerance towards practices that might be considered as errors:

COMMENT je fais des erreurs je ne peux pas dire que je ne fais pas des erreurs mais je suis bien déjà je avec ă: (.) même en écriture parce que au début deux trois ans j'étais pas capable d'écrire UN MOT en français (.) vraiment sans regarder le mot dans le dictionnaire j'étais pas capable de l'écrire (.) à ce moment-là depuis quand je commence à travailler dans l'école ça s'en vient sans regarder (.) j'écris okay j'ai fait une erreur (.) grave pas (.) on s'en va comme ça (.) c'est bien (.)

Her written French prevented her from entering college to become a nurse:

j'ai (.) essayé (.) trois fois d'entrer dans une collège comme d'être infirmière (.) mais (.) j'ai pu pas passer écriture en français (.) j'ai passé le test oral mais écriture non (.) et c'était la même problème I ă: le même problème parce que (.) tous ceux qui on attend en roumaine on écrit chaque lettre (.) en francais non (.) et j'ai toujours ce problème-là (.)

Labor is a crucial sector of social participation in capitalistic economies because it is a necessary condition for reproduction. Expectations towards legitimate or majorized linguistic repertoires are thresholds to (well paid) jobs. But work is an important environment for language learning in a usage-based perspective, because people spend a great deal of time at work and, depending on the sort of labor, it affords more or less communication in different media and languages. Comparing her own learning conditions with those of her husband, Natalia reflects on these circumstances for learning in a very nuanced manner which contributes to developing strategies for developing voice:

moi je j'ai (.) j'ai appris plus vite la langue parce que j'ai dû (.) j'étais dans le magasin premièrement (.) et tous les clientes parlaient en français (.) ă: (.) après à l'école ă: (.) j'ai eu une ă: (.) une mediu comme ça pour apprendre plus vite ă: la langue mais lui non (.) c'est pour ça parce que LUI (.) travaillait à la [anonym.] (.) majorité c'était moldaves aussi et roumaine (.) après il a suivi le cours de français (.) après la francisation on est allé les deux à la cette usine ă: comme assembleuse assembleur (.) et moitié du travailleur là-bas étaient aussi roumaines et russes et n'a pas eu besoin de tra de parler en français trop [...] MOI parce que j'étais obligée pratiquement et sincèrement à l'école je me suis donné plus vite à parler je me suis libérée de cette barrière ă: de la (.) ă: (.) parce que je faisais avant beaucoup plus des erreurs en parlant ă: (.) comme à ce moment-là depuis quand j'ai commencé à travailler dans une école parce que les élèves te corrigent vite et moi je suis ouverte pour ă: (.) pour apprendre comme il faut comme je suis persévérante (.) et c'est pour ça que j'ai appris plus vite ou plus bien (.) c'est comme ça (.)

Initially working in a shop (with Russian-speaking colleagues) and in a factory, she was detached from the professional discourses of her expertise. Under these conditions, it was difficult to learn an L2 (and even maintain an L1) and acquire voice in a new environment, since she had very few possibilities to language use and lacked access to communication in French. This has changed with working at school. Labour as space of social practice has thresholds - once Natalia had access to the institution, she had access to social practices that allowed her to learn. In her current job as a substitute teacher, her plurilingualism is helpful in contact with equally multilingual pupils to make herself understood, but also to be respected:

comme je travaille à l'école je parle avec les élèves à l'école même en français des fois en anglais des fois en russe des fois en roumaine ă: (.) n'importe dans quelle langue ă: ă: (.) en anglais je parle moins (.) ă: aussi avec beaucoup des erreurs mais russe roumaine et français (.) je parle (unv.) avec les élèves (.)

But although her multilingualism is clearly an asset for her pedagogical practice, and her repertoire unfolds a certain scope at school, it is not officially valued as qualification. Having a voice has several levels here: being understood and respected by pupils in everyday interaction but also convincing school authorities, colleagues, parents of her linguistic and pedagogical competences. In a transformative perspective her 
voice to be heard, to have an effect would mean recognition of plurilingual competences in a more fundamental way. It would mean to question linguistic regimes at school and to fight discriminatory, glottophobic behaviour.

Natalia has experienced the non-recognition of her voice when speaking French. Accent-based glottophobia occurs also in schools. Natalia has psychological resources to confront this and to keep believing in her linguistic resources, resulting in what she calls "being proud" of her repertoire:

j'ai eu aussi peur du du parce que les élèves sont des fois méchants (.) et (.) ils rient du mon accent (.) ă: (.) j'ai eu des problèmes comme ça mais pour l'accent par exemple je dis je peux dire tout ça toujours ça je suis fière de mon accent (.) oui j'ai une accent mais je suis tellement fière den mon accent parce que je parle russe je parle roumaine je parle français je essaie de comprendre anglais (.) et peut être qu'on (unv.) avenir je vais parler aussi en anglais et si j'ai un accent oui oui (.) c'est ma fièrté (.) <laughs> et avec ça après tous les élèves (.) ont commencé à (.) à (.) aimer comme ils disaient <<imitates> oh madame avec accent madame avec accent> (.) c'était drôle c'était $f$ / c'était intéressant (.) e:t (.) après j'ai passé entrevue pour être enseignante suppléante [...] j'adore être enseignante suppléante parce que (.) je suis toujours responsable de ce que on a à faire (.) mais avec les élèves c'est (.) un petit peu difficile de travailler (.) mais en même temps c'est un plaisir quand tu rentres dans une classe avec la positivité avec le sourire (.) avec ă: la bonheur et tu demandes toute la classe vous êtes okay aujourd'hui (.) si quelqu'un me dit uhm parce que j'ai eu un jour comme ça une élève qui m'a dit ouais pas pire (.) pOURQUOI LA VIE EST BELLE (unv.) des yeux des oreilles (.) wow (.) et pensant la période que j'ai vécue (.) et quand je regarde il sont nés ici ils sont chANCEUX mais ils ne voient pas ça (.) et je les raconte comme ça ma vie comme ça parce que des fois les profs laissent justement comme ă: une film à regarder des exercices à faire quelque chose à ça et j'ai du temps à animer un petit peu la classe (.)

Her way of approaching the pupils shows that interpersonal and emotional factors influence whose voice is accepted and listened to. Thanks to her pedagogical engagement, Natalia wins the pupils' hearts. By doing so she also gains authority as a teacher despite her difficult position as supply teacher and can ultimately transmit multilingualism as a value. Her self-representation as a proud speaker of her idiolect and of various languages is both a condition for making her voice heard and a result of it. This is an important strategy for coping with sociolinguistic relations that disadvantage her. It could also be an important step towards awareness rising and ultimately the transformation of linguistic regimes that favour sociolinguistic unequality - but it does not automatically mean that she has a voice.

Having voice and developing voice can mean different things in Natalia's biography. As a pupil and student, it meant being listened to and being respected by classmates and teachers. It implied having academic registers in medicine in Romanian (and Russian, to some degree). It was about adapting her way of speaking Romanian to different social and geographic situations. It meant having authority as a doctor. And, of course, it also meant making herself understood in everyday situations not covered in our interview. After moving to Canada, her first focus was to make herself understood in everyday situations, something that she could take for granted in Moldova. But it also meant learning the linguistic resources necessary to find a job. At first, her priority was to earn money. She worked in jobs that did not require qualifications or extensive linguistic knowledge, but that provided only limited possibilities to acquire new linguistic knowledge.

In the long term, she looked for jobs that would be more fulfilling (and better paid). Extensive knowledge of French, including writing, was a condition even for the recognition of her diploma or for supplementary studies, as was knowledge of English in many cases. Her evolving linguistic repertoire gave her access to other kinds of jobs, but none of which demanded the qualification she had acquired in Moldova. Voice also depends on the contexts in which it can be articulated. Natalia does not have the same possibilities of speaking in Québec as she had in Moldova, because her daily activities and everyday communication differ. Although Natalia appreciates the seemingly less severe correctness ideologies in Québec, she is still categorized as a stranger and as having an accent. She confronts this with self-esteem and humor. Giving up her position when emigrating included giving up part of the privilege that voice is.

\section{Participation, voice and autonomy}

Usage-based approaches (Bybee, 2006; Tomasello, 2012) see speaking as a social practice among other ways of interacting. Individual language learning is driven by a strive for autonomy (Maas, 2008, 272; Castellotti \& Moore, 2011) or voice (Blommaert, 2010, p. 180 ; Blommaert \& Backus, 2013, p. 29 ; Busch, 2016), especially when children first learn to speak but also when adults learn new ways of acting in an unfamiliar context that affords language learning (Ben Harrat \& Zeiter, in this number; Zeiter, 2019b, p. 151). Mobile adults like Natalia who have to live and act in a new language before speaking and writing it 
have individual reasons for wanting to learn a language, individual forms of autonomy they are striving for (Zeiter, 2019a). This does not require the individual to be conscious of this or explicitly aim to learn to have autonomy (even less so at an early age, in the ontogenetic perspective). Increased autonomy via language learning (according to Maas, 2008, p. 283) starts from the premise that language learning is always learning the language of others. This is why interaction is a precondition for learning and speaking always subject to the others' scrutiny suggest reserving "autonomy" as the aim of language learning processes in a strict sense of acquiring the means to communicate in that language, especially in the ontogenetic perspective, but also for L2 learning in the context of migration into different linguistic relations. Participation is a formal criterion that is abstract from meaning and content. I propose using the notion voice in the sense of being heard when expressing interests, opinions, political claims. The content and aim of speech acts should not be neglected. Speaking means challenging the hearer, expecting something from them (Wolfram, 2018, p. 54).

Participation (in different fields of social, economic and political life) is certainly one dimension of the scope of linguistic resources; access to these linguistic means is a condition for their scope. Participation is closely related to how liberal democratic states are legitimated via participation (Blanchet, 2016, p. 35). In this sense, ideas of participation often reflect "Minority World norms", which Tisdall \& Punch (2012, p. 254) underline in respect to "notions of appropriate participation for children and young people [that are] not even universal in their own contexts." Wolfram (2018, p. 9) notes that a condition for participation is that it is not assigned and those who want to or are supposed to participate can define their roles as participants themselves. Decisive is who invites whom to do what (Wolfram, 2018, p. 14). Participation is a condition for transformation and resistance, but these are not the number one political aims in discourse about participation. Here is a difference between participating and having voice. Whereas the former can imply access to existing forms of participation, creating the conditions for voice means transforming social structures such as creating spaces in which voices can be articulated and heard (Pennycook, 2001, p. 39 ; Weirich, 2018, pp. 72-75; Weirich, 2021c). Only a notion of voice understood as potentially transformative adds to existing discussions of participation and sociolinguistic inequalities.

Political participation and transformation are the core of having voice compared to other forms of successful communication: the ability to intervene for one's interests, on a local level and in various social contexts. Its conditions are that linguistic forms at the individual's or group's disposal are understood, heard and accepted as a position to be negotiated, and can be convincing (Heffer, 2013). Having a voice and standing up for one's interests, then not only mean active complicity but can have a transformative dimension. Political initiatives that aim to increase participation must attempt to transform structures in a way that they keep barriers to participation low. None of this will give groups and individuals voice; it will eliminate obstacles that hinder the realization, articulation and enhancement of voices.

If a "named" language (Otheguy et al., 2015) and, more specifically, a standard variety of it is the vehicular language of a democratic state, the capacity to communicate in that language is a prerequisite for participation, e.g. French in Québec for Natalia. Access to this capacity is unequally distributed. The education system is put into place to teach children (and some adults) the necessary knowledge. Legitimate claims in liberal democratic states can thus demand equal access to education and language learning - demanding the state to keep its promise of participation. The extensive Francisation program in Québec is important in this respect. An underlying premise is that languages and registers can be learned. But when it comes to participation and voice, speakers considered "non-native" or speakers of nonstandard varieties tend to be considered less legitimate as Natalia experiences (Blanchet, 2016 ; Boudreau, 2016 ; Cameron, 2012, p. 255). If this claim to participation is to be taken seriously, it has to account for the multilingual repertoires of citizens and inhabitants and also the different social conditions for learning. But it could also mean providing for translation and guaranteeing participation in languages other than the state language. This is neither a problem of comprehension nor equality, but it contests the official language's symbolic and legitimation functions.

Having access to the labor market is an economic condition for living in capitalist societies, and having fair wages is a condition for social participation. One may need voice to defend one's interests as an employee or to have an opinion considered in a team meeting. However, jobs that require specific linguistic skills, but do not presuppose that workers already have them, can contribute to acquiring voice as they provide a context in which to practice language (such as substitute teacher). They are also crucial for having a voice, because they attribute roles to speakers from which they articulate their voice (Wolfram, 2018, p. 13). The example of Natalia shows how mobility confines her to a completely different segment of the labor market than she was educated for in Moldova and Romania.

In many cases, it makes sense to speak about participation and having voice at the same time because the former requires the latter - one cannot fully participate without being heard, e.g. in political 
organizations or the realm of literature and narrative. Other types of participation necessitate communication but not necessarily voice (in the sense of "making oneself heard").

\section{Conclusion: Conditions of voice}

Voice (in the sense of "making yourself heard") can describe sociolinguistic inequalities related to speakers' potential to make themselves heard and understood. It is justified to speak of having voice as an aim in language learning processes, as described by Natalia's example. Analyses that use the notion of voice in this sense have to consider that being heard does not solely depend on linguistic aspects but also other political and socio-economic factors. Social structures enable or disable agency (Assmann, 2008) in a macro-perspective of social and sociolinguistic relations (Zeiter, 2019a). The literature on voice reveals a complex picture of its conditions, particularly Hymes' works (see Weirich et al., in this number). The analysis of Natalia's account shows that voice is not only a privilege in itself, but also depends on other, intersectional, privileges such as being considered as non-québécoise or migrant by potential employers.

Linguistic and non-linguistic privileges and ideologies shape the conditions for being heard. Hymes' $(1983 / 1996)$ critical notion of voice implicates the listener and society at large. Individuals and groups speak in the context of social relations that have many implicit criteria for recognizing speakers (or not) and to attribute more or less value to their voice. A condition for voice is being listened to. Speakers are at the mercy of listeners - and this especially if the potential or desired listeners are more powerful. Every analysis of particular instances of voice has to consider the audience, the interlocutor and what ideologies and attitudes shape the basis for interaction.

In societies where some people and groups are structurally excluded from being heard, having a voice is a privilege (hooks, 1999, p. 338 "right to voice, to authorship, a privilege"). Privileges often appear invisible to those who have them, because they are not reflected upon, treated as given for everyone (and therefore not a privelege) or being the result of effort/merit. It is the lack of privilege that is felt, not the privilege itself. Biographic ruptures like migration reposition individuals as speakers, and sometimes the loss of voice makes a former privilege palpable. As in the case of other privileges, those who have it do not recognize it, for example because they tend to view the distribution of voice as justified by merit and a lack of voice as a result of personal failure. This discourse is so overwhelming that non-privileged speakers also adopt this view. Creating the conditions for having a voice means challenging sociolinguistic relations and privileges. Does having voice necessary involve forms of inclusion? Technically, not everyone can (and should) speak at the same time (even if on a global scale over a range of social spaces, of course many people speak at the same time) and we have limited capacities in time and cognitive resources to listen to others. To some extent that means: if one person is speaking, others are not. Which is why it is important to observe who takes up most of the time speaking. Many institutions that function via verbal exchange, regulate the distribution of voice and limit the duration of contributions. This is not necessarily possible or desirable for any social space but it is certainly an important contribution to redistributing voice.

Understanding linguistic ideologies that silence non-privileged speakers can be a condition for refraining from judging other speakers and oneself based on accents, syntax, or orthography, for example. In such circumstances arise possibilities for creating spaces that are less silencing. Natalia builds her selfconscious voice as allophone teacher on her rejection of judgement of grammatical "errors" and of accents. Hereby she fights strategies of silencing. And still she acts within categories that allow to identify linguistic practices as defective. Exercise is a necessary condition for elaborating linguistic repertoires. Social spaces and institutions that have linguistic entry (or participation) criteria, but do not provide conditions for acquiring these means, are exclusive. A prerequisite for any individual to find their voice is exercise, and therefore access to the form of communication in which they want to develop a voice. Developing strategies to overcome barriers, anxiety and linguistic insecurity is a further prerequisite. Recognizing harmful linguistic ideologies and developing a critical attitude towards them can help, as Natalia's experience shows.

From a linguistic point of view, we can describe the linguistic forms and means necessary to have voice in different social situations, noting that these linguistic means will have different impacts depending on the speaker and the situation. Because of this context-specificity, I doubt that it is possible to deduce schemes and criteria that can be applied in the analysis of interaction based on which we can say whether someone does or does not have voice. I suggest to treat voice as a more abstract term that can be developed in theory and used to interpret social situations and human interaction. Linguistic disciplines such as conversation analysis and discourse studies provide appropriate means to analyze micro-instances of interactions with the scope to study phenomena such as discrimination, inclusion and exclusion, and other forms of inequality. A rich tradition of research with linguistic biographies provides a means to shed light on these phenomena from biographic perspectives. 
Weirich, Anna-Christine. «The privilege of voice as a criterion for sociolinguistic inequalities ». Nouvelle Revue Synergies Canada, №15 (2022)

\section{Notes}

${ }^{1}$ Pseudonym.

${ }^{2}$ A fellowship by the Volkswagen Stiftung made this work possible.

${ }^{3}$ A linguistic repertoire consists of all the linguistic and communicative means at the disposition of a speaker. It is structured by experience and practice (Blommaert / Backus 2013).

${ }^{4}$ The name of the language is controversial and remains highly politicized. According to the Constitution of Moldova, the name of the state language is Moldovan. In 2013, the Constitutional Court of Moldova implicitly decided to call the state language of Moldova Romanian, even if the constitution uses a different glottonym. The controversy of the name of the language stems from its being associated with different nationalisms and geopolitical orientations (Weirich, 2015).

\section{Transcription conventions}

(.) short pause

[...] omission

I Anakoluth

(unv.) unintelligible

<action while speaking> 
Weirich, Anna-Christine. «The privilege of voice as a criterion for sociolinguistic inequalities ». Nouvelle Revue Synergies Canada, №15 (20221).

\section{References}

Amesberger, H., \& Halbmayr, B. (2008). Das Privileg der unsichtbarkeit. Rassismus unter dem Blickwinkel von Weisssein und Dominanzkultur. Braumüller.

Assmann, A. (2008). Einführung in die Kulturwissenschaft: Grundbegriffe, Themen, Fragestellungen (2nd ed.). Schmidt.

Bakhtin, M. M. (1981). Discourse in the Novel (1934-35). In M. Holquist (ed.), The Dialogic Imagination. Four essays by M.M.Bakhtin (pp. 259-422). University of Texas Press.

Ben Harrat, M., \& Zeiter, A.-C. Positionnements sociaux en L2 : entre pratiques sociales et acquisitions langagières. Nouvelle Revue Synergies Canada (in this number).

Blanchet, P. (2016). Discriminations. Combattre la glottophobie. Textuel.

Blommaert, J. (2008). Bernstein and poetics revisited: Voice, globalization and education. Discourse \& Society, 19(4), 425-451. DOI: 10.1177/0957926508089938.

Blommaert, J. (2010). The Sociolinguistics of Globalization. Cambridge University Press.

Blommaert, J., \& Backus, A. (2011). Repertoires revisited: 'Knowing language' in superdiversity. Working

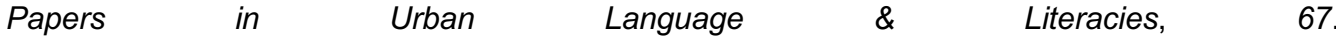
https://www.academia.edu/6365319/WP67 Blommaert and Backus 2011. Repertoires revisit ed Knowing language in superdiversity. [last access: July, 2nd, 2021]

Blommaert, J., \& Backus, A. (2013). Superdiverse repertoires and the individual. In I. de Saint-Georges and J. J. Weber (eds.), Multilingualism and multimodality. Current challenges for educational studies (vol 2, 11-32). Sense Publishers.

Boudreau, A. (2016). À l'ombre de la langue légitime. L'Acadie dans la francophonie. Classiques Garnier.

Busch, B. (2016). Heteroglossia of survival: To have one's voice heard, to develop a voice worth hearing. Working Papers in Urban Language \& Literacies, 188. https://www.academia.edu/20304151/WP188 Busch 2016. Heteroglossia of survival To hav e ones voice heard to develop a voice worth hearing [last access: July, 2nd, 2021].

Bybee, J. (2006). From usage to grammar: The mind's response to repetition. Language in Society, 82(4), 711-733.

Cameron, D. (2012). Epilogue. In K. Hyland \& C. Sancho Guinda (eds.), Stance and voice in written academic genres (pp. 249-256). Palgrave Macmillan.

Castellotti, V., \& Moore, D. (2011). Compétence plurilingue et pluricultruelle. Genèses et évolutions. In : P. Blanchet \& P. Chardenet (Eds.), Guide pour la recherche en didactique des langues et des cultures. Approches contextualisées (pp. 241-252). Éditions des archives contemporaines.

Das, S. (2008). The talk of tamils in multilingual montreal: A study of intersecting language ideologies in nationalist Quebec. Studies in Ethnicity and Nationalism, 8(2), 230-247.

Heffer, C. (2013). Projecting Voice: Towards an Agentive Understanding of a Critical Capacity. Cardiff.

Heller, M. (2008). Languages and the Nation-State. Challenges to sociolinguistic theory and practice. Journal of Sociolinguistics, 12(1), 504-524.

hooks, b. (2015). Talking back. Thinking feminist, thinking Black. Routledge. (Original work published 1989).

hooks, b. (1999). talking back. In R. Ferguson \& M. Tucker (Eds.), Out there. Marginalization and contemporary cultures, (pp. 337-340). The MIT [Massachusetts Institute of Technology] Press. 
Horner, K., \& Weber, J.-J. (2018). Interest convergence and divergence in luxembourgish language-ineducation policy. In A. Weirich \& E. Caporal-Ebersold (Eds.), Éducation plurilingue et pratiques langagières. Hommage à Christine Hélot (pp. 185-201). Peter Lang.

Hymes, D. (1996). Report from an underdeveloped country: Toward linguistic competence in the United States. In D. Hymer (Ed.), Ethnography, Linguistics, Narrative Inequality, (pp. 63-105). Taylor\&Francis. (Original work published 1983)

Juffermans, K., \& van der Aa, J. (2013). Introduction to the special issue: Analyzing voice in educational discourses. Anthropology \& Education Quaterly, 44(2), 112-123.

Maas, U. (2008). Sprache und Sprachen in der Migrationsgesellschaft. V\&R Unipress.

Mclntosh, P. (1988). White privilege and male privilege: a personal account of coming to see correspondences through work in women's studies. Wellesley Centers for Women. Working Paper, 189.

Mclntosh, P. (2012). Reflections and future directions for privilege studies. Journal of Social Issues, 68(1), 194-206. DOI: 10.1111/j.1540-4560.2011.01744.x.

Otheguy, R., García, O., \& Reid, W. (2015). Clarifying translanguaging and deconstructing named languages: A perspective from linguistics. Applied Linguistics Review, 6(3), 281-307.

Pavlenko, A. (2005). Emotions and Multilingualism. Cambridge University Press.

Pennycook, A. (2001). Critical Applied Linguistics. A Critical introduction. Erlbaum.

Sebba, M. (2013). Multilingualism in written discourse: an approach to the analysis of multilingual texts. International Journal of Bilingualism, 17(1), 97-118.

Siegal, M. (1996). The role of learner subjectivity in second language sociolinguistic competency: Western women learning Japanese. Applied Linguistics, 17(3), 356-382.

Tisdall, E. K. M., \& Punch, S. (2012). Not so 'new'? Looking critically at childhood studies. Children's Geographies, 10(3), 249-264. DOI: 10.1080/14733285.2012.693376.

Tomasello, M. (2003). Constructing a language. A usage-based theory of language acquisition. Harvard University Press.

Weirich, A.-C. (2014). Majorized linguistic repertoires in a nationalizing state. In K. Horner, I. de SaintGeorges \& J.-J. Weber (Eds.), Multilingualism and Mobility in Europe. Policy and Practices (pp. 149-170). Peter Lang.

Weirich, A.-C. (2015). Einige Gedanken zu aktuellen Entwicklungen des Glottonymstreits in der Republik Moldova. Quo Vadis, Romania?, (46), 106-129.

Weirich, A.-C. (2018). Sprachliche Verhältnisse und Restrukturierung sprachlicher Repertoires in der Republik Moldova. Peter Lang.

Weirich, A.-C. (2021a) Access and reach of linguistic repertoires in periods of change. A theoretical approach to sociolinguistic inequalities. International Journal of the Sociology of Language.

Weirich, A.-C. (2021b). Italian as minority language, foreign language and language of migration in the Republic of Moldova. In A. Sorescu-Marinković, M. Dragnea, T. Kahl, B. Njagulov, D. L. Dyer, \& A. Costanzo (Eds.), Language and the Politics of Identity. The Romance-Speaking Balkans (pp. 76-114). Brill.

Weirich, A.-C. (2021c) Surveillez cet espace, on parle peut-être de vous. Pratiques d'écriture informelle dans les annonces de rencontres du journal Métro montréalais. Polygraphes .

Weirich, A.-C., Zeiter, A.-C., Ben Harrat, M., \& Macé, F. Introdution. Nouvelle Revue Synergies Canada (in this number). 
Weirich, Anna-Christine. «The privilege of voice as a criterion for sociolinguistic inequalities ». Nouvelle

Wolfram, G. (2018). Die Kunst, für sich selbst zu sprechen. Essay. Bundeszentrale für politische Bildung.

Zeiter, A.-C. (2019a). Déconstruire la motivation pour rencontrer le désir (de langue). Revue TDFLE (actes $\mathrm{n}^{\circ} 1$ ). $\mathrm{https}: / /$ doi.org/10.34745/numerev_1350.

Zeiter, A.-C. (2019b). Silence, on s'occupe de vous ! Barrières à la socialisation langagière dans l'accueil des requérants d'asile en Suisse. Minorités linguistiques et société/Linguistic minorities and society, 12, 148-166. 